DOI: $10.31866 / 2410-1311.36 .2020 .221069$

УДк 005.332.7-057.177.4:159.954

\title{
- КОМУНІКАТИВНІ ЗДІБНОСТІ В РОБОТІ ІВЕНТ-МЕНЕДЖЕРА
}

\author{
- Короленко Євгенія Олегівна ${ }^{1 a}$, Швець Ірина Григорівна ${ }^{2 a}$ \\ - ${ }^{1}$ Aсистент, \\ ORCID: 0000-0003-1552-0394, e-mail: k-e-o@ukr.net, \\ ${ }^{2}$ Aсистент, \\ ORCID: 0000-0002-4847-6097, e-mail: mandarina1912@ukr.net, \\ аКиївський національний університет культури і мистецтв, \\ вул. Є. Коновальця, 36, Київ, Україна, 01133
}

\section{- Для цитування:}

Короленко, Є.О., Швець, І.Г. (2020). Комунікативні здібності в роботі івент-менеджера. Питання культурології, (36), 219-227. doi: https://doi.org/10.31866/2410-1311.36.2020.221069.

\section{Анотація}

Мета статті - дослідження ролі та значення комунікативних здібностей у професійній діяльності івент-менеджерів. Вирішення поставленої мети реалізується у завданнях, які полягають у окресленні специфіки постмодерної культури споживання, що актуалізує інтерес до івент-сфери та тенденцій розвитку соціокультурної практики сьогодення. Методологія дослідження передбачає використання аналітичного методу, який застосовується 3 метою виділення основних характеристик, що притаманні постмодерній культурі споживання. Задіяний метод синтезу для виокремлення ролі комунікації у функціонуванні івент-менеджменту. Прогностичний метод залучено задля окреслення перспектив розвитку сфери івент-менеджменту. Івент-менеджмент прикладна галузь, яка має мінливий характер. Аналіз цієї сфери є актуальним, зважаючи на відсутність її ґрунтовного теоретичного опрацювання. Наукова новизна дослідження полягає у висвітленні комунікативного характеру івент-сфери. Висновки. Значною мірою організація проєктів пов'язана з постійною комунікацією між різними суб'єктами - організаторами, менеджерами та замовниками культурних послуг. Ïх інтеракція є перманентною та такою, що проявляється на різних етапах організації івенту. Комунікація є не лише формою взаємодії учасників проєктної діяльності, а й способом трансляції культурних цінностей. Відповідно, необхідною умовою для роботи івентменеджера виступає наявність розвинених комунікативних якостей. Розвиток івентменеджменту пов'язаний з швидкою адаптацією до змінюваних соціокультурних реалій. В умовах викликів, які постають перед людством, виникають нові форми взаємодії, що пов'язані з технічними засобами та поширенням онлайн-комунікації. Підкреслюється роль комунікативного начала, яке $\epsilon$ не лише формою інтеракції, а й базисним модусом культури. Діяльність івент-менеджерів безпосередньо пов'язана з комунікацією, тому 
доцільним вбачається оволодіння основами ораторського мистецтва, що сприятиме успішній професійній діяльності.

Ключові слова: івент-менеджмент; менеджер; проєкт; комунікація; культура

\section{Вступ}

Соціокультурний простір сьогодення набуває значних трансформацій. Вектор розвитку суспільства пов'язаний з функціонуванням культури споживання. Вона обумовлює потребу у формуванні конкурентоспроможного товару, який би був спрямований на задоволення потреб різних споживачів. Водночас відбувається зростання кількості установ, чия діяльність орієнтована на івент-сферу. За таких умов стає актуальною проблема виховання кадрів, які будуть сприяти просуванню того чи іншого культурного продукту. Однією з якостей, що необхідна для івент-менеджерів $є$ розвинені комунікативні здібності. Дане питання потребує ґрунтовного висвітлення, адже дозволить скорегувати специфіку здійснення підготовки такого типу спеціалістів.

Ключові поняття, які стосуються івент-менеджменту окреслювались у праці О. Дементьєвої (2019), базовими для івент-менеджерів є розробки Джо Голдблата (Goldblatt, 2004). Івент-менеджмент в індустрії дозвілля досліджено в статті М. Поплавського (2017). Огляд та систематизація підходів, які використовуються при організації подій, здійснено в роботі С. Єрмакова, Ю. Макаренко, М. Соколова (Ермаков и др., 2017). Удосконаленню технологій івент-маркетингу присвячено працю колективу авторів - М. Мухіної та ін (Мухина и др., 2019). Своєрідність ціннісних настанов суспільства споживання та риси постмодерної культури аналізуються в статтях А. Постола (2010), А. Курилової та Д. Тіхазе (Курилова \& Тихазе, 2011). Специфіка взаємодії культурних інститутів та проєктів в сучасному українському просторі окреслюється в праці А. Тормахової (2016). Івент-менеджмент $€$ галуззю, яка активно розвивалась протягом останніх років. Проте реалії функціонування сучасного ринку сфрери дозвілля унаочнюють необхідність перегляду тих якостей, якими має володіти менеджер. В ряді розробок вітчизняних та закордонних авторів хоча й окреслювались аспекти, які пов'язані з івент-менеджментом, проте комунікативні аспекти у даній діяльності досі не ставали предметом окремих досліджень.

\section{- Мета статті}

Дослідження ролі та значення комунікативних здібностей у професійній діяльності івент-менеджерів. Вирішення поставленої мети реалізується у завданнях, які полягають у окресленні специфіки постмодерної культури споживання, що актуалізує інтерес до івент-сфери та тенденціях розвитку соціокультурної практики сьогодення. Методологія дослідження передбачає використання аналітичного методу, який застосовується з метою виділення основних характеристик, які притаманні постмодерній культурі споживання. Задіяний метод синтезу для виокремлення ролі комунікації у функціонуванні івент-менеджменту. Прогностичний метод залучено задля окреслення перспектив розвитку сфери івент-менеджменту. Новизна дослідження полягає у висвітленні комунікативно- 
го характеру івент-сфери. Значною мірою організація проєктів пов'язана з постійною комунікацією між різними суб'єктами - організаторами, менеджерами та замовниками культурних послуг. Їх інтеракція $€$ перманентною та такою, що проявляється на різних етапах організації івенту.

\section{- Виклад матеріалу дослідження}

Івент-менеджмент є невід'ємною частиною культури XXI століття, яка розвивається в межах настанов постмодернізму. Домінантним принципом епохи стає потреба у формуванні різноманітного культурного продукту. Його виникнення обумовлене функціонуванням схеми: запит - відповідь. Культурний продукт виникає як результат, спрямований на задоволення потреби споживачів. Проте можлива й зворотна ситуація, коли створюються умови, завдяки яким буде виникати потреба у вже наявному продукті.

Постмодернізм є часом, коли набувають особливого значення культура споживання, причому мова йде про різноманітність форм, які є затребуваними в суспільстві. Подібний плюралізм товарів та послуг також виступає однією з панівних ознак часу. Хоча постмодерні реалії по-різному інтерпретуються сучасними мислителями, проте ряд ідеологів вбачають витоки тих тенденцій, що наявні у культурі, у розвитку політики неоконсерватизму, яка супроводжується фетишизацією споживання. «Зокрема, 3. Бауман, Д. Белл та Ю. Хабермас трактують постмодернізм як результат політики та ідеології неоконсерватизму, для якого характерний естетичний еклектизм, фретишизація предметів споживання та інші риси постіндустріального суспільства» (Постол, 2010, с. 70). Акцент на культурі споживання та ії̈ значне поширення протягом останніх десятиліть може сприйматися як певне явище, що має негативну конотацію, проте важливим є розуміння механізму функціонування цього процесу.

Особливість постмодерної ситуації полягає у тому, що раніше культура споживання змінювала характер й значення культурних продуктів та матеріальних цінностей. На першому плані була утилітарна функція, проте тепер її замінює знакова фрункція, що зазначають А. Курилова та Д. Тіхазе. Наявність бажаного у модерну добу означала задоволення потреби, але відтепер цього замало. «В сучасному ж суспільстві цього насичення не відбувається, через те, що речі грають тут абсолютно іншу роль: вони постають у вигляді одиниць культурного обміну, несуть в собі не утилітарну, а знакову функцію. Головним стає не задоволення суто практичної потреби, а бажання за допомогою речі влитися в культурний діалог, налагодити і постійно підтримувати комунікацію із зовнішнім світом» (Курилова \& Тихазе, 2011, с. 37-38). Тобто сорера івент-менеджменту є засобом просування культурного товару, який потребує споживач.

Реалії XXI ст. пов'язані з особливим статусом івент-менеджменту, який постає інструментом організації подій в культурному та мистецькому просторі сьогодення. М. Поплавський наголошує на тому, що доцільно аналізувати їх як механізм управління. «Event-технології розглядаються як механізм функціонального координування всіх спеціалістів, які причетні до створення й проведення спеціального заходу. У межах управлінського підходу event може розглядатися з точки зору фрункцій художньо-творчої діяльності та її складових» (Поплавський, 
2017 , с. 188). Розвиток івент-сфери та поширення в суспільному просторі унаочнюють системний характер діяльності івент-менеджерів. Практика організації івентів потребує залучення ряду теоретичних знань та практичних навичок, які сприятимуть досягненню поставленої мети, що полягає у реалізації проєкту. Це поєднання знань стратегій розвитку культури, специфріки організації рекламних компаній, аналітичної роботи. Більшість дослідників схиляються до думки, що всі моделі життєвого циклу проєкту мають ряд спільних рис і можуть бути представлені у вигляді базової схеми Дж. Голдблата (Goldblatt, 2004), що складається з п'яти основних етапів: дослідження, розробка, планування, координація та оцінка. На всіх етапах організації культурного проєкту важливою складовою роботи івент-менеджерів є комунікація, яка здійснюється між членами команди та ще більшою мірою з іншими учасниками, які так чи інакше залучаються до проєктної діяльності. На етапі дослідження відбувається моніторинг ситуації, існуючої потреби у івенті та аналізі того, на яку кількість учасників він має бути розрахований. Вже на першому етапі мають проявлятися не лише аналітичні здібності івент-менеджера, а й комунікативні якості. На етапі розробки відбувається пошук ідей, що також супроводжується аналогічними процесами. «Успішний план - це безперервний пошук нових ідей за допомогою мозкового штурму для генерації ідей і Mind Mapping для їх синтезу» (Ермаков и др., 2017, с. 144). Лише на третьому етапі, який пов'язаний з плануванням, можливе зменшення комунікації із клієнтом. Адже в цей період менеджер має прорахувати специфіку використання часу, простору та наявних ресурсів. Але і на даному етапі можливе безпосереднє спілкування із замовником чи іншими суб'єктами, що є дотичними до реалізації проєкту. На наступному етапі, який представлений координуванням процесу виконання плану, комунікативні якості мають бути постійно задіяні. Так само на завершальному етапі, який пов'язаний з оцінюванням результатів проведення івенту, важливим є спілкування з замовником, учасниками проєкту, яке може проходити через опитування чи інші фрорми зворотного зв'язку.

О. Дементьєва (2019) у своїй розробці «Основні поняття event-менеджменту» згадує 7Р мікс-маркетинг, враховуючи який можна продуктивно втілювати та розробляти event-заходи, що допомагає успішно працювати на ринку, пов'язаному з культурним продуктом: «... є 7 складових даного підходу, в центрі яких завжди знаходиться клієнт. До них відносяться: продукт, його ціна, поширення продукту, його просування, персонал, процес просування і підтвердження» (с. 42). Виходячи з позиції клієнтоорієнтованості стає зрозумілим, що взаємодія із замовником, як і шляхи реалізації проєкту, побудовані здебільшого саме на комунікації. Комунікативний процес варто розуміти ширше, ніж безпосереднє спілкування з замовником чи колегами по проєктній діяльності. Власне сама сорера культури стає комунікацією, де відбувається обмін повідомленнями між адресатом та реципієнтом, причому повідомленням може бути мистецький твір, аудіальна чи візуальна практика.

Специфіка івент-сфери полягає у тому, що вона має прикладний характер, в ній відсутні чіткі та однозначні сценарії, які б унеможливили появу проблемних питань. Вона передбачає постійний пошук та здатність до швидкої модифікації засобів реалізації проєкту. Дослідники відзначають потребу у пошуку власних 
методик в івент-менеджменті: «Методом «спроб і помилок», аналізуючи власний досвід та розробку конкурентів, у кожній компанії створюється власний підхід до організації корпоративних заходів. Але кожна з цих технологій організації хоча і розроблена майже досконально, проте все одно не є ідеальною» (Мухина и др., 2019, с. 350-351). Практика модифікації підходів у івент-менеджменті обумовлена мінливістю соціокультурної діяльності. Серед проблем, які можуть спричиняти складнощі в реалізації івентів, виділяють такі, як ультракороткі терміни контрактів, демпінг (продаж товарів та послуг за цінами, що нижче ринкових), великі ризики. Разом з тим внаслідок того, що ринок івент-менеджменту має відкритий характер, він передбачає легкість у прийнятті нових рішень та можливості адаптації до певних незвичних умов.

Івент-сфера в сучасній культурі відіграє ряд важливих функцій, які не обмежуються задоволенням базових потреб, а й виступають показником тих змін, які відбуваються у суспільстві. Так різноманітні івенти, як вірно відмічено А. Тормаховою, постають формою активізації діяльності культурних інституцій, а також провідною практикою, що віддзеркалює суспільні запити. «Попри те, що своєрідною ознакою сучасного культурного простору є спрямованість на економічну обґрунтованість доцільності здійснення будь-яких культурних ініціатив, в останні роки можна спостерігати підвищення ролі культурних проєктів як засобу активізації та відродження традиційних інститутів» (Тормахова, 2016, с. 13).

Необхідно вказати на суттєві проблемні питання, які стосуються сорери сучасного івент-менеджменту. Внаслідок пандемії COVID-19 та поширення карантинних заходів, виникли кризові ситуації у економіці більшості країн світу, які вплинули безпосередньо і на розвиток культури. Скасування більшості івентів, які були заплановані у першій половині 2020 року, спричинили скорочення кількості заходів, що були реалізовані. Пандемія стала своєрідним викликом, який сприяв перегляду доцільності проведення проєктів. Разом з тим зросла кооперація між представниками соціокультурної та мистецької сорери з різних країн світу. На регулярній основі почали організовуватись онлайн-заходи, які повинні були заповнити прогалину, що виникла внаслідок відсутності офлайн-проєктів. Дж. Голдблат та C. Лi (Lee \& Goldblatt, 2020) у передмові до восьмого видання розробки, присвяченій івент-менеджменту, зазначають, що пандемія коронавірусу є часом для «ресрлексії, інновацій та рішень» (р. XXV). Попри не найкращі в економічному плані часи, івент-менеджмент продовжує розвиватись, адже опинившись перед труднощами активізується потреба в оновленні та створенні нових можливостей створення, відтворення та просування культурного продукту. На відміну від тих ініціатив, які функціонували у XX ст., що мали здебільшого офлайн фрорму, наразі існує чимало можливостей для впровадження онлайн-комунікації. Щобільше, її інтенсивність має бути не меншою, ніж при безпосередньому спілкуванні, а й навіть більшою. Тому можна відзначити актуальність розвитку комунікативних якостей івент-менеджерів, що мають реалізовуватись різними шляхами.

Актуальним завданням для івент-менеджера $€$ розвиток навичок комунікації. Певні люди більше схильні до соціальної інтеракції, проте у разі відсутності яскраво виражених комунікативних здібностей, доцільним $є$ опанування основ ораторського мистецтва. Звернення до технік, пов'язаних з красномовством, 
сприятиме успішній професійній діяльності івент-менеджера, адже його ефективність обумовлена здатністю переконувати у перевагах пропонованого культурного продукту цільову аудиторію. Окрім цього здобуті навички можна буде застосовувати для повсякденного спілкування.

\section{- Висновки}

Івент-менеджмент - прикладна галузь, що має мінливий характер. Значною мірою організація проєктів пов'язана з постійною комунікацією між різними суб'єктами - організаторами, менеджерами та замовниками культурних послуг. Ïх інтеракція $є$ перманентною та такою, що проявляється на різних етапах організації івенту. Комунікація $€$ не лише формою взаємодії учасників проєктної діяльності, а й способом трансляції культурних цінностей. Відповідно необхідною умовою для роботи івент-менеджера $€$ наявність розвинених комунікативних якостей. Зміна соціокультурних умов обумовлює модифікацію типу проєктів, актуалізуючи потребу їх проведення в онлайн-фрормі. Це стимулює розвиток різних форм активності та стає поштовхом для впровадження інновацій в івентменеджмент.

\section{- Список використаних джерел}

Дементьева, А. О. (2019). Основные понятия event-менеджмента. StudNet, 2(4), 41-44.

Ермаков, С. Г., Макаренко, Ю. А., \& Соколов, Н. Е. (2017). Event-менеджмент: обзор и систематизация подходов к организации мероприятий. Управленческое консультирование, 9(105), 140-148.

Курилова, А. С., \& Тихазе, Д. К. (2011). Язык общества потребления: коммуникативная функция вещи. Вестник Российского университета дружбы народов. Серия: Социология, 2, 37-43.

Мухина, М. В., Каткова, О. В., Мухина, Е. С., Авдонина, Д. С., \& Бочкарева, Ю В. (2019). Совершенствование технологий event-маркетинга. Инновационная экономика: перспективы развития и совершенствования, 2(36), 348-354.

Поплавський, М. М. (2017). Event-менеджмент у індустрії дозвілля. Питання культурології, 33, 186-197.

Постол, А. А. (2010). Постмодернізм як сучасна суспільно-політична реальність. Гуманітарний вісник Запорізької державної інженерної академії, 42, 69-79.

Тормахова, А. (2016). Специфіка взаємодії культурних інститутів та проектів в сучасному українському просторі. Університетська кафредра, 5, 7-14.

Goldblatt, J. J. (2004). Special Events: Event Leadership for a New World (4 ${ }^{\text {th }}$ ed.). John Wiley \& Sons.

Lee, S., Goldblatt, J. (2020). Special Events: The Brave New World for Bolder and Better Live Events (8 ${ }^{\text {th }}$ ed.). Wiley.

\section{- References}

Dement'eva, A. O. (2019). Osnovnye ponyatiya event-menedzhmenta [Basic concepts of event management]. StudNet, 2(4), 41-44 [in Russian].

Ermakov, S. G., Makarenko, Yu. A., \& Sokolov, N. E. (2017). Event-menedzhment: obzor i sistematizatsiya podkhodov k organizatsii meropriyatii [Event-management: Review 
and Systematization of Approaches of the Organization of Events]. Upravlencheskoe konsul'tirovanie, 9(105), 140-148 [in Russian].

Goldblatt, J. J. (2004). Special Events: Event Leadership for a New World (4 ${ }^{\text {th }}$ ed.). John Wiley \& Sons [in English].

Kurilova, A. S., \& Tikhaze, D. K. (2011). Yazyk obshchestva potrebleniya: kommunikativnaya funktsiya veshchi [The language of consumer society: communicative role of thing]. Vestnik Rossiiskogo universiteta druzhby narodov. Seriya: Sotsiologiya, 2, 37-43 [in Russian].

Lee, S., \& Goldblatt, J. (2020). Special Events: The Brave New World for Bolder and Better Live Events. ( $8^{\text {th }}$ ed.). Wiley [in English].

Mukhina, M. V., Katkova, O. V., Mukhina, E. S., Avdonina, D. S., \& Bochkareva, Yu. V. (2019). Sovershenstvovanie tekhnologii event-marketinga [Improving the technologies of event-marketing]. Innovatsionnaya ekonomika: perspektivy razvitiya i sovershenstvovaniya, 2(36), 348-354 [in Russian].

Poplavskyi, M. M. (2017). Event-menedzhment u industrii dozvillia [Event management in the leisure industry]. Issues in Cultural Studies, 33, 186-197 [in Ukrainian].

Postol, A. A. (2010). Postmodernizm yak suchasna suspilno-politychna realnist [Postmodernism as modern socio-political reality]. Humanitarian Bulletin of Zaporozhye State Engineering Academy, 42, 69-79 [in Ukrainian].

Tormakhova, A. (2016). Spetsyfika vzaiemodii kulturnykh instytutiv ta proektiv v suchasnomu ukrainskomu prostori [The specificity of the interaction between cultural institutions and projects in the Ukrainian space]. Universytetska kafedra, 5, 7-14 [in Ukrainian].

\title{
- COMMUNICATIVE SKILLS IN THE WORK OF EVENT MANAGER
}

\author{
- Yevheniia Korolenko'a, Iryna Shvets ${ }^{2 a}$ \\ ${ }^{1}$ Assistant, \\ ORCID: 0000-0003-1552-0394, e-mail: k-e-o@ukr.net, \\ ${ }^{2}$ Assistant, \\ ORCID: 0000-0002-4847-6097, e-mail: mandarina1912@ukr.net, \\ ${ }^{a}$ Kyiv National University of Culture and Arts, \\ Kyiv, Ukraine
}

\section{Abstract}

The purpose of the article is to review the role and importance of communication skills in the professional activities of event managers. To support the researched issue, there are goals to outline the specifics of the postmodern culture of consumption, which updates the interest in the event sphere and trends in the sociocultural practice of today. The research methodology involves the use of an analytical method, which is used to identify the main characteristics that are inherent in the postmodern culture of consumption. The synthesis method is used to highlight the role of communication in the functioning of event management. The predictive method is used to outline the prospects for the development of event management. Event management is an application industry that has a changing nature. The analysis of this applied 
field is relevant, given the lack of its thorough theoretical elaboration. The scientific novelty is to highlight the communicative nature of the event sphere. Conclusions. To a large extent, the project implementation is associated with constant communication between different participants. They are organizers, managers and customers of cultural services. Their interaction is permanent and manifests itself at different stages of the event organization. Communication is not only a form of interaction between project participants but also a way of translating cultural values. Accordingly, a necessary condition for the work of the event manager is the presence of developed communicative qualities. The development of event management is associated with rapid adaptation to changing sociocultural realities. In the face of the challenges facing humanity, new forms of interaction are emerging, involving technical means and the spread of online communication. The role of the communicative principle is emphasized, which is not only a form of interaction but also a fundamental mode of culture. Event managers' work is directly involved in communication, so it is advisable to master the basics of public speaking, which will contribute to successful professional activity.

Keywords: event management; manager; project; communication; culture

\title{
- КОММУНИКАТИВНЫЕ СПОСОБНОСТИ В РАБОТЕ ИВЕНТ-МЕНЕДЖЕРА
}

\author{
- Короленко Евгения Олеговна ${ }^{1 a}$, Швец Ирина Григорьевна2а \\ - ${ }^{1}$ Aссистент, \\ ORCID: 0000-0003-1552-0394, e-mail: k-e-o@ukr.net, \\ ${ }^{2} \mathrm{Accuстент,}$ \\ ORCID: 0000-0002-4847-6097, e-mail: mandarina1912@ukr.net, \\ аКиевский национальный университет культуры и искусств, \\ Киев, Украина
}

\section{- Аннотация}

Цель статьи - исследование роли и значения коммуникативных способностей в профессиональной деятельности ивент-менеджеров. Решение поставленной цели реализуется в задачах, которые заключаются в определении специфики постмодернистской культуры потребления, актуализирующей интерес к ивент-сфере и тенденций развития социокультурной практики современности. Методология исследования предполагает использование аналитического метода, который применяется с целью выделения основных характеристик, присущих постмодернистской культуре потребления. Задействован метод синтеза для очерчивания роли коммуникации в функционировании ивент-менеджмента. Прогностический метод привлечен для определения перспектив развития сферы ивент-менеджмента. Ивент-менеджмент прикладная отрасль, которая имеет изменчивый характер. Анализ этой сферы является актуальным, учитывая отсутствие ее основательной теоретической обработки. Новизна исследования заключается в освещении коммуникативного характера ивентсферы. Выводы. В значительной степени организация проектов связана с постоянной 
коммуникацией между различными субъектами - организаторами, менеджерами и заказчиками культурных услуг. Их интеракция является перманентной и такой, которая проявляется на разных этапах организации ивента. Коммуникация становится не только формой взаимодействия участников проектной деятельности, но и способом трансляции культурных ценностей. Необходимым условием для работы ивент-менеджера выступает наличие развитых коммуникативных качеств. Развитие ивент-менеджмента связано с быстрой адаптацией к изменяющимся социокультурным реалиям. В условиях вызовов, стоящих перед человечеством, возникают новые формы взаимодействия, связанные с техническими средствами и распространением онлайн-коммуникации. Подчеркивается роль коммуникативного начала, которое выступает не только формой интеракции, но и базисным модусом культуры. Деятельность ивент-менеджеров непосредственно связана с коммуникацией, поэтому целесообразным является овладение основами ораторского искусства, способствующего успешной профессиональной деятельности.

Ключевые слова: ивент-менеджмент; менеджер; проект; коммуникация; культура 